\title{
LEGO CENTER DI PEKANBARU DENGAN PENDEKATAN ARSITEKTUR KUBISME
}

\section{LEGO CENTER IN PEKANBARU WITH CUBISM ARCHITECTURE APPROACH}

\author{
Jacob Adha Putra ${ }^{1)}$, Mira Dharma Susilawaty ${ }^{2)}$ \& Pedia Aldy ${ }^{3)}$ \\ 1)Mahasiswa Prodi Arsitektur Fakultas Teknik Universitas Negri Riau, Indonesia
}

2, 3) Dosen Prodi Arsitektur Fakultas Teknik Universitas Negri Riau, Indonesia

Diterima: Desember 2020; Disetujui: Januari 2021; Dipublikasi: April 2021

*Corresponding author: jacobputra10@gmail.com

\begin{abstract}
Abstrak
Banyaknya masyarakat yang berminat terhadap mainan LEGO membuat mainan LEGO menjadi terkenal. mulai banyaknya event-event yang diselenggarakan di mall atau convention center terhadap mainan LEGO, memunculkan ide untuk merancang LEGO Center. ide ini muncul karena tidak adanya tempat yang mengkhususkan untuk kegiatan menggunakan mainan LEGO tersebut. tujuan perancangan bangunan LEGO Center ini adalah sebagai tempat pameran, dan sebagai tempat rekreasi yang bersifat edukasi dengan menggunakan LEGO. Menggunakan tema arsitektur kubisme, yang dimana pemikirian ini timbul dari sudut pandang LEGO yang memiliki tiga dimensi panjang, lebar dan tinggi. Konsep pada rancangan LEGO Center di Kota Pekanbaru ini menggunakan konsep "Tumpukan LEGO Bricks" yang dihasilkan dari keterkaitan objek rancangan dan tema Arsitektur Kubisme terhadap objek rancangan yang memiliki penyederhanaan bentuk-bentuk kotak atau kubus sesuai dengan sifat Kubisme.
\end{abstract}

Kata Kunci : LEGO, LEGO Center, Kubisme, Tumpukan LEGO Bricks

\begin{abstract}
Many people who are interested in LEGO toys make LEGO toys famous. starting from the many events held in the mall or convention center for LEGO toys, come up with ideas to create a LEGO Center. This idea arises because there is no place that specializes for activities using these LEGO toys. the purpose of designing this LEGO Center building is as an exhibition venue, and as an educational recreation area using LEGO. Using the Cubist architecture theme, which is where thinking comes from the perspective of LEGO which has three dimensions of length, width and height. The concept of the LEGO Center design in Pekanbaru City uses the concept of "Piles of LEGO Bricks" resulting from the linkage of the Cubism Architecture design objects and themes to the design objects which have simplified forms of squares or cubes in accordance with the nature of Cubism.
\end{abstract}

Keywords: LEGO, LEGO Center, Cubism, LEGO Bricks Stacks 
How to Cite : Jacob Adha Putra, Mira Dharma Susilawaty, Pedia Aldy (2020). LEGO Center di Pekanabru dengan Pedekatan Arsitektur Kubisme, JAUR (Journal of Architecture and Urbanism Research). 4 (2): 96104.. 


\section{PENDAHULUAN}

$L E G O$ adalah sejenis alat permainan yang terbuat dari bongkahan plastik kecil. Alat permainan ini sangat terkenal di dunia khususnya di kalangan anak-anak atau remaja, tidak pandang laki-laki maupun perempuan. Bongkahan-bongkahan dan kepingan benda ini bisa disusun menjadi model apa saja mulai dari kendaraan, bangunan, kota, binatang bahkan pesawat luar angkasa. Menyusun LEGO tidak hanya dapat membuat bangunan atau kendaraan saja, melainkan dengan cara yang kreatif dapat menghasilkan sebuah karya seni yang menarik.

Terkenalnya LEGO juga membuat banyaknya orang memulai hobi bermain dan mengkoleksi $L E G O$. Dengan hobi yang sama membuat banyaknya orang untuk berkumpul dan mendirikan sebuah komunitas. Di Indonesia sendiri terdapat komunitas pecinta $L E G O$ yang bernama Klub LEGO Indonesia atau yang sering disebut dengan KLI. KLI didirikan dengan tujuan untuk mengumpulkan semua pecinta $L E G O$ yang ada di Indonesia. KLI juga secara aktif terlibat dan berkontribusi dengan bebagai kegiatan yang dipersiapkan oleh ALJ, ALJ adalah offical distributor LEGO yang ada di Indonesia. Salah satu Event yang diikuti KLI adalah Olympic Brick Festival dengan Biggest Minifigures Habitat dan Olympic Theme Diorama. Dalam acara ini, 1.000 mini habitat LEGO hasil karya anggota KLI dipamerkan dan dicatat dalam Museum Rekor Indonesia (MURI). Yang berlangsung di Baywalk Mall, Jakarta, 5 sampai 25 September 2016. Dan di Pekanbaru sendiri terdapat event LEGO Creative Carnaval yang berlangsung di Mall Ciputra Pekanbaru, 20 Desember 2018 sampai 6 Januari 2019.

Event LEGO sering berlangsung di Mall atau convention center, tidak adanya tempat untuk mewadahi inilah yang memunculkan ide untuk membuat LEGO Center di Pekanbaru, LEGO Center adalah sebuah pusat $L E G O$ di Pekanbaru yang mana tujuan dari gedung ini adalah sebagai tempat pameran yang bertemakan LEGO, sebagai tempat berinteraksi sosial, tempat untuk kegiatan yang berhubungan dengan LEGO, dan sebagai tempat rekreasi yang yang bersifat edukasi untuk masyarakat Pekanbaru sehingga masyarakat Pekanbaru dapat bermain, belajar, dan menciptakan karya dengan menggunakan LEGO. Untuk itu LEGO Center ini diharapkan mampu menjadi tempat masyarakat Pekanbaru untuk meningkatkan dan mengembangkan minat terhadap $L E G O$.

Dalam merancang gedung pusat $L E G O$ ini, tema yang tepat untuk digunakan adalah arsitektur kubisme. Pemikirian ini timbul dari sudut pandang $L E G O$ ini yang memiliki 3 (tiga) dimensi panjang, lebar dan tinggi, sedangkan istilah panjang lebar dan tinggi merupakan istilah untuk bentuk-bentuk geometri, dalam dunia arsitektur terdapat aliran khusus yang mempunyai karakteristik geometris yaitu aliran Kubisme. Kubisme termasuk dalam aliran arsitektur modern awal Fungsionalisme atau rasionalisme. Elemen bangunan mengutamakan pada fungsi yang pada akhirnya dapat menimbulkan keindahan tanpa adanya hiasan atau dekorasi satupun.

Aliran cubism memanfaatkan teknologi beton bertulang. Sistem ini menjadikan suatu bangunan dibangun dalam waktu yang cepat dan memungkinkan dibangun dalam jumlah yang banyak. Elemen- elemen bangunan dibuat dan dicor di pabrik yang selanjutnya perakitan dapat dilakukan di lapangan secara langsung serta memerlukan waktu yang singkat. Bagian-bagian dari bangunan seperti pondasi, kolom, tiang, tangga dan lain-lain dibuat di pabrik, kemudian dipasang dan disambung menjadi bangunan dalam jumlah sesuai kebutuhan. Elemen utama pendukung arsitektur cubism yaitu material, ruang dan pencahayaan. Dalam arsitektur klasik, material yaitu hal utama yang memperlihatkan kekuatan dalam konstruksi. Ruang terletak dibalik dinding tebal di mana cahaya masuk 
hanya sedikit. Namun semenjak arsitektur cubism muncul, ruang menjadi aspek paling dominan.

Sejak Kubisme, ahli Sejarah mengatakan bahwa arsitektur bukan lagi seperti selubung, tetapi ruang menjadi aspek dominan dan merupakan unsur utama, aspek kedua pencahayaan, dan aspek ketiga adalah material (Yulianto,2005).

Berdasarkan uraian di atas, maka dibutuhkan suatu sarana demi menunjang kebutuhan atas minat masyarakat terhadap $L E G O$. Karena itu dengan adanya suatu wadah yang memadai dengan fasilitas yang lengkap, sehingga dapat meningkatkan kemampuan dan bakat serta mendorong minat masyarakat terutama para remaja. Dengan perkembangan yang ada, diharapkan $L E G O$ Center di Pekanbaru dapat melengkapi kebutuhan dalam kegiatan dan dalam pelayanannya ditunjang oleh sarana dan prasarana yang representatif sehingga memenuhi aspek-aspek yang dibutuhkan berdasarkan permasalahan yang ada.

\section{METODE PENELITIAN}

Paradigma Perancangan, Sebagai tempat para pecinta LEGO untuk melakukan kegiatan-kegiatan positif mereka maka LEGO Center di Pekanbaru nantinya akan memiliki desain yang menggunakan konsep "Tumpukan LEGO Bricks" yang dihasilkan dari keterkaitan objek rancangan dan tema Arsitektur Kubisme terhadap objek rancangan yang memiliki penyederhanaan bentuk-bentuk alam secara geometris (berkotak-kotak) yang memiliki panjang,tinggi dan lebar sesuai dengan sifat Kubisme.

Strategi perancangan LEGO Center di Pekanbaru dengan Pendekatan Arsitektur Kubisme adalah sebagai berikut :

Survei dilakukan untuk mengetahui data-data yang diperlukan, seperti $L E G O$ itu sendiri, proses pembuatan $L E G O$, sejarah
LEGO, kondisi eksisting tapak, mulai dari potensi hingga permasalahan tapak sebagai dasar yang digunakan dalam perancangan sesuai dengan fungsi dan hingga minat masyarakat Pekanbaru terhadap LEGO itu sendiri.

Analisa tapak bertujuan untuk mengetahui kelebihan dan kelemahan pada tapak bagi perancangan $L E G O$ Center sehingga dalam perancangan mengetahui strategi dalam perancangan LEGO Center. Analisa tapak berupa kondisi eksisting tapak, orientasi matahari, utilitas, sirkulasi, kebisingan dan analisa lainya yang dibutuhkan.

Analisa Fungsional, bertujuan untuk mengetahui hal-hal atau aktivitas apa saja yang akan diwadahi oleh bangunan LEGO Center, seperti kegiatan pada bangunan, pengguna dan standar dalam perancangan fungsi dan lainlain.

Program Ruang, bertujuan untuk memperhitungkan dan mengetahui kebutuhan ruang untuk mewadahi kegiatan LEGO Center.

Penzoningan, bertujuan untuk membedakan fungsi dan kegiatan pada ruang yang dibedakan antar zona sesuai sifatnya seperti ruang publik, semi privat, privat dan servis. Ini bertujuan untuk memudahkan dalam mengatur tatanan massa dan tatanan luar sesuai dengan kondisi tapak LEGO Center.

Konsep Perancangan, akan menjadi dasar dan acuan dalam perancangan $L E G O$ Center. Konsep yang digunakan adalah $L E G O$ Bricks, pemilihan ini diambil dari keterkaitan $L E G O$ yang memiliki penyederhanaan bentuk secara geometris (kotak-kotak) sesuai dengan Arsitektur Kubisme.

Bentukan Massa, yang dihasilkan berdasarkan dengan tema, konsep perancangan dan hasil dari analisa tapak. Pendekatan arsitektur yang diambil dalam perancangan LEGO Center ini adalah arsitektur Kubisme.

Sirkulasi Ruang Dalam, merupakan penghubung antar ruang baik secara horizontal maupun vertikal. 
Sirkulasi Ruang Luar, bertujuan untuk membedakan antara sirkulasi kendaraan umum, kendaraaan pribadi dan pejalan kaki.

Tatanan Massa, bangunan berdasarkan tema arsitektur Kubisme dan disusun berdasarkan penzoningan yang sesuai dengan memaksimalkan potensi site,fungsi ruang, dan lingkungan sekitar.

Sistem Struktur, pada LEGO Center meliputi sistem struktur bawah berupa pondasi, struktur tengah kolom dan balok dan struktur bentang lebar untuk area pameran dan stuktur lainnya yang akan dibutuhkan dalam perancangan.

Tatanan Ruang Dalam, dirancang sesuai dengan kebutuhan ruang dan penzoningan ruang. Ruang dibuat sesuai dengan standar perancangan ruang.

Tatanan Ruang Luar, akan ditata sesuai dengan massa bangunan perancangan LEGO Center. tatanan ruang luar berupa perletakan zona yang terdapat pada ruang luar, berupa zona parkir, zona servis, vegetasi dan lain-lain yang dianggap perlu dalam perancangan.

Fasad bangunan LEGO Center disesuaikan dengan konsep dan tema perancangan arsitektur kubisme.

Hasil rancangan berupa hasil akhir yang didapat dari kajian-kajian teori pada fungsi dan tema yang diambil. Meliputi hasil rancangan akan berupa transformasi desain, perlengkapan gambar kerja dan 3D.

\section{PEMBAHASAN}

Lokasi tapak berada di Pekanbaru yang merupakan ibukota Provinsi Riau. Lokasi tepatnya berada di Jalan Jendral Sudirman kecamatan Pekanbaru Kota terletak di depan MTQ Pekanbaru.

Luas tapak perancangan yaitu $15.000 \mathrm{~m}^{2}$ $(1.5 \mathrm{Ha})$, kondisi lahan kosong dan kontur tapak relative datar. Fasilitas infrastruktur pada tapak cukup memadai yaitu jaringan listrik, jalan raya pada sisi tapak dan saluran pembuangan roil kota.

Batas-batas pada tapak yaitu, pada utara, SPBU Arifin Ahmad, pada selatan, Stadion Gelanggang Remaja, pada barat, terdapat lahan kosong, dan pada timur tapak, terdapat Jalan Jendral Sudirman dan MTQ.

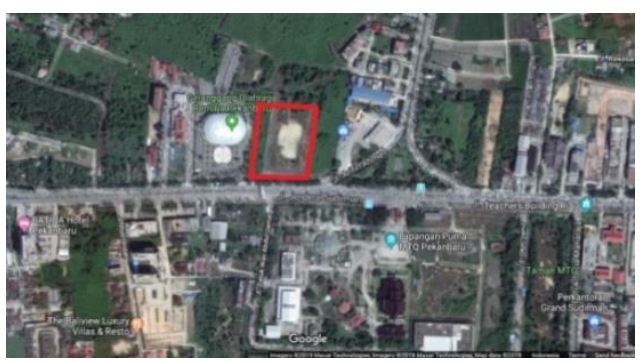

Gambar 1. Lokasi dite

Gaya bangunan menganut aliran arsitektur kubisme yang mengutamakan bentuk-bentuk penyederhanaan alam secara geometris (berkotak-kotak). Berdasarkan konsep dasar yaitu "LEGO Bricks" pemilihan bentuk dasar diarahkan bentukan $L E G O$ yang memiliki penyederhanaan bentuk-bentuk alam secara geometris (berkotak-kotak) sesuai dengan sifat Kubisme. Pemilihan bentuk LEGO yang tersusun saling menumpuk ini dianggap mewakili konsep rancangan. Sehingga melalui bentukan ini, LEGO Bricks dianggap sebagai salah satu konteks yang mampu mewakili representasi dari $L E G O$ sendiri.

Penzoningan, Ruang-ruang pada $L E G O$ Center akan dikelompokkan menjadi 3 kelompok yaitu, zona public, zona semi privat, dan zona privat.

Zona public adalah zona yang bisa diakses oleh seluruh pengguna bangunan, yang termasuk dalam zona public adalah ruang parkir, lobby, foodcourt,cafe, Pameran LEGO,LEGO Miniland, Museum LEGO, serta taman $L E G O$.

Zona semi privat adalah zona yang diakses oleh semua pengguna dengan syaratsyarat tertentu, fungsi yang termasuk dalam 
zona ini yaitu ruang Gallery $L E G O$, area bermain sambil belajar $L E G O$ serta Musholla.

Zona privat adalah zona yang hanya diakses pengguna tertentu pada bangunan, fungsi yang termasuk dalam zona ini yaitu, semua ruang fungsi pengelola, ruang keamanan, ruang kebersihan, serta ruang $\mathrm{ME}$.

Penzoningan menurut aspek fungsi pada tapak yaitu, Zona Pameran, adalah sebagai tempat pameran $L E G O$ yang dimana terdapat berbagai macam rancangan $L E G O$ yang menakjubkan. Zona Edukasi, adalah sebagai tempat dimana bermain LEGO dengan edukasi dan terdapat juga museum LEGO mulai dari jenis-jenis $L E G O$ yang lama hingga sekarang. Zona Wisata, adalah tempat dimana berbagai macam $L E G O$ yang bisa dimaikan hingga pajangan miniatur kota dari $L E G O$. Enterance/Pintu Masuk, adalah tempat masuknya pengunjung dan tempat dimana bisa dengan mudah mengakses ke zona-zona lainnya.

Bentuk gubahan massa ditempatkan pada bagian tengah tapak, lalu bangunan dihadapkan ke arah timur, karena view yang terbaik dari tapak ke luar. Untuk Tata letak muka bagunan, sebaiknya diletakan menghadap Jalan Jendral Sudirman. Karena letak wajah Bangunan pada sebuah bangunan akan mempengaruhi pada pengalaman visual orang yang melihatnya. Pembedaan visual yang kentara akan mendorong orang yang melihat bangunan untuk berfikir dan mengutarakan pendapatnya berdasarkan apa yang dirasakan.

Penerapan arsitektur kubisme pada massa bangunan yaitu dengan bentuk kotakkotak. Pemilihan bentuk $L E G O$ yang tersusun saling menumpuk ini dianggap mewakili konsep rancangan. Sehingga melalui bentukan ini, LEGO Bricks dianggap sebagai salah satu konteks yang mampu mewakili representasi dari $L E G O$ sendiri.

Warna adalah atribut yang paling menyolok untuk membedakan suatu bentuk dari lingkungannya. Menggunakan warna Putih dan abu-abu pada bangunan yang digunakan pada LEGO Center agar tidak terkesan asing pada lingkungan sekitarnya dan menggunakan warna-warna yang netral. Pemilihan warna ini didasarkan pada tema yaitu arsitektur kubisme yang dimana Elemen bangunan mengutamakan pada fungsi yang pada akhirnya dapat menimbulkan keindahan tanpa adanya hiasan atau dekorasi satupun.

Konsep yang diterapkan pada LEGO Center ini adalah "Tumpukan LEGO Bricks". Konsep ini terinspirasi dari tumpukan $L E G O$ yang dihasilkan dari keterkaitan objek rancangan dan tema Arsitektur Kubisme terhadap objek rancangan yang memiliki penyederhanaan bentuk-bentuk alam secara geometris (berkotak-kotak) yang memiliki panjang,tinggi dan lebar sesuai dengan sifat Kubisme. Pemilihan bentuk LEGO yang tersusun saling menumpuk ini dianggap mewakili konsep rancangan. Karena dalam bentukan ini dapat membuat interior yang luas dan ruang yang saling terhubung yang dimana aristektur kubisme mengutamakan ruang sebagai hal yang utama.

Konsep "Tumpukan LEGO Bricks" sesuai dengan tema arsitektur kubisme yang dimana aritektur kubisme selalu Memiliki panjang,tinggi dan lebar. memiliki komposisi bidang kotak, kubus dan balok. Dan mengutamakan ruang sebagai yang utama. Sehingga bentukan "Tumpukan LEGO Bricks" ini menghasilkan ruang dalam yang luas dan saling terhubung satu sama lain. Bentukan ini dapat berbentuk seperti LEGO sehingga akan memberikan kesan kontras atau unik pada bangunannya. Bentuk bangunan menggunakan bentukan geometri dasar lebih dari satu massa bangunan, dimana pada perancangan LEGO Center ini menggunakan bentuk dasar kotak,kubus dan balok.

Penerapan konsep pada bentuk bangunan yaitu berupa kumpulan bangunan kubus dan balok yang bentuk dasarnya 
terinspirasi dari $L E G O$. LEGO memiliki bentuk yang berbeda tetapi selalu memiliki sisi kotakkotak.Bangunan terdiri dari 4 massa yang sebenarnya terintregasi menjadi 1 kesatuan. Dimana jumlah massa disesuaikan olah zonasi aktivitas atau kegiatan yang terdiri dari 4 zona yaitu area pamaeran, rekreasi, edukasi, dan yang mengghubungkan ketiga zona tersebut adalah lobby yang berada ditengah. Besaran dan tinggi elevasi setiap massa disesuaikan dengan kebutuhan dan kapasitas pengguna di setiap zona. Di bagian atap gedung terdapat bentukan bulat seperti bentuk bagian atas $L E G O$ yang diggunakan untuk skylight.

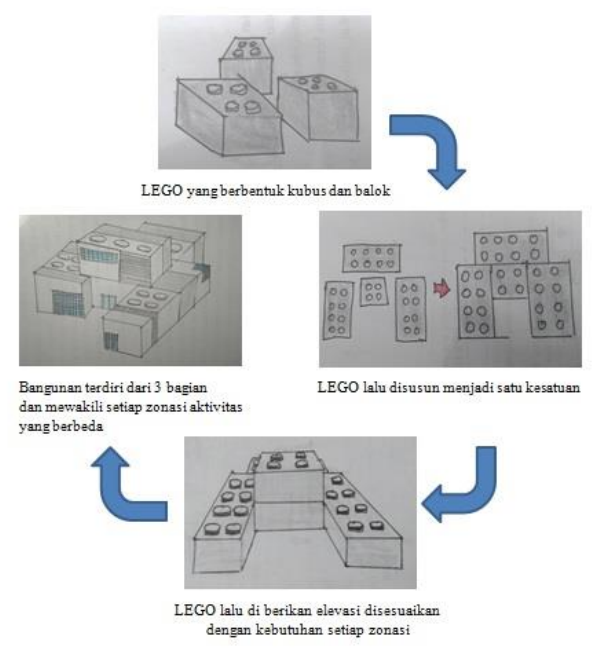

Gambar 2. Bentukan Konsep

Konsep tapak pada perancangan $L E G O$ Center di Pekanbaru ini terdiri dari, pola tatanan massa, tatanan area sekitar, tatanan lanskap yang sesuai dengan konsep dasar yaitu "Tumpukan LEGO Bricks". Pada konsep ini merupakan hasil pemilihan dan penggabungan alternatif pada analisis yang dipaparkan pada bab sebelumnya. Yang dimana "Tumpukan LEGO Bricks".memiliki penyederhanaan bentuk-bentuk alam secara geometris (berkotak-kotak).

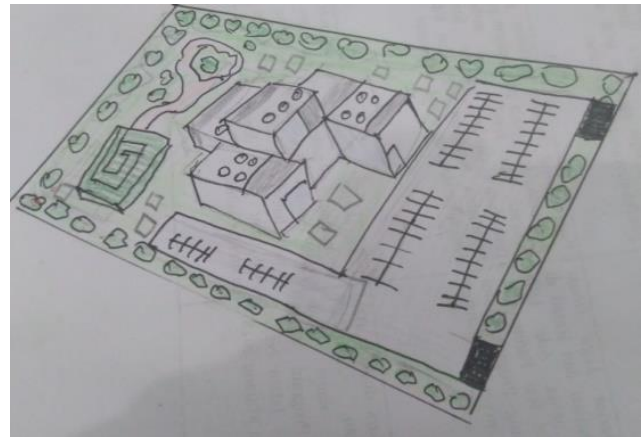

Gambar 3. Bentukan Konsep Tapak

Pola aksesibilitas dan sirkulasi merupakan hasil dari analisis pada tahap sebelumnya, pada perancangan ini Zona parkir diletakkan pada bagian yang langsung terhubung pada jalan, agar mudah dijangkau oleh kendaraan, zona kegiatan outdoor diletakan pada bagian barat tapak yang view nya langsung menghadap hutan. Setiap zona menerapkan konsep "Tumpukan LEGO Bricks" yang memiliki bentuk-bentuk alam secara geometris (berkotak-kotak). Sirkulasi pada tapak ini terbagi atas beberapa zona, yaitu zona kendaraan, zona pejalan kaki dan zona sirkulasi servis. pada perancangan ini zona sirkulasi kendaraan pada tapak dibatasi hanya pada bagian depan, yang kemudian dapat diakses dengan berjalan kaki. Sedangkan konsep sirkulasi servis pada tapak menggunakan pola searah dengan zona yang berbeda dengan sirkulasi lain dan hanya dapat diakses oleh petugas servis.

Konsep ruang ini merupakan hasil dari penataaan ruang yang didasari dari analisisi ruang sehingga memunculkan alternatif yang paling sesuai dalam penzoningan ruang. Konsep ruang dalam bangunan dirancang berdasarkan penerapan konsep dasar perancangan serta tema arsitektur kubisme yang menjadikan ruang yang menjadi dominan. Menggunakan beton polos tanpa menggunakan aksesoris. Serta konsep Tumpukan LEGO Bricks diaplikasikan melalui perulangan-perulangan elemen pada interior dan warna-warna pada ruang interior. Perbedaan dari tiap layout dan sirkulasi yang 
disesuaikan pada setiap zona aktivitas Pameran, Rekreasi , Edukasi dan area servis dan pengelola. Selain itu juga adanya perpaduan permainan lighting, warna, furniture/ properti dan komponen-komponen interior yang ingin dibentuk sesuai kegiatan pada ruang tersebut.

Dapat dilihat pada gambar berikut, tiap zona memiliki dinding beton dan berwarna abu-abu atau putih, lighting dan ceiling sangat diperhatikan sehingga menghasilkan suasana tertentu. Pada zona Edukasi, suasana yang ingin dibangun adalah cheerful dan penuh dengan permainan lighting yang berwarnawarni. Pada zona Pameran, membawa suasana dramatik pada malam hari dengan adanya lighting yang memfokuskan LEGO yang akan di Pamerkan. Pada zona Rekreasi ingin membawa suasana yang alami dan natural yang didukung dengan adanya taman $L E G O$, sedangkan pada zona servis dan pengelola, disesuaikan dengan kebutuhan yang membutuhkan cahaya alami yang cukup.

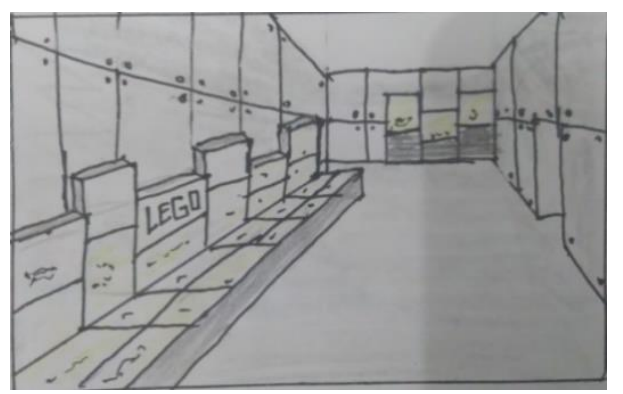

Gambar 4. Interior Ruang Pameran

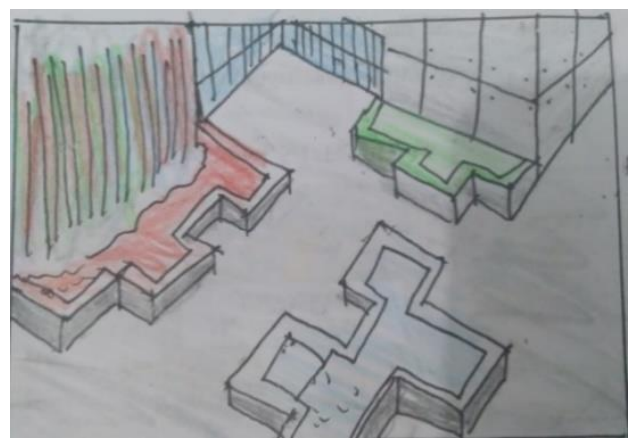

Gambar 5. Interior Ruang Pameran

\section{SIMPULAN}

Perancangan LEGO Center dengan Pendekatan Arsitektur Kubisme ini bertujuan untuk memberikan wadah bagi masyarakat di Pekanbaru untuk tempat pameran $L E G O$, serta sebagai rekreasi dan edukasi yang bertemakan LEGO. Selain itu LEGO Center ini juga menampung kegiatan komunitas dan event yang masih berhubungan dengan LEGO. Fasilitas yang terdapat di LEGO Center yaitu, fungsi utama seperti fungsi pameran terdapat tempat pameran $L E G O$ serta Gallery LEGO. Pada fungsi rekreasi terdapat LEGO Miniland serta taman yang bertemakan $L E G O$. Fungsi edukasi, terdapat fasilitas berupa museum $L E G O$ dan ruang bermain sambil belajar menggunakan $L E G O$.

Menggunakan tema arsitektur kubisme, yang dimana pemikirian ini timbul dari sudut pandang $L E G O$ yang memiliki 3 (tiga) dimensi panjang, lebar dan tinggi, sedangkan istilah panjang lebar dan tinggi merupakan istilah untuk bentuk-bentuk geometri yang terdapat dalam arsitektur kubisme. Elemen bangunan mengutamakan pada fungsi yang pada akhirnya dapat menimbulkan keindahan tanpa adanya hiasan atau dekorasi satupun. Elemen utama pendukung arsitektur kubisme yaitu material, ruang dan pencahayaan. Konsep yang digunakan pada LEGO Center adalah "LEGO Bricks" yang dihasilkan dari keterkaitan objek rancangan dan tema Arsitektur Kubisme terhadap objek rancangan yang memiliki penyederhanaan bentuk-bentuk alam secara geometris (berkotak-kotak) sesuai dengan sifat Kubisme.

\section{DAFTAR PUSTAKA}

Yulianto S. 2005. Arsitektur Modern. UGM Press: Yogjakarta.

Ferdiansah, R. (2018). Perancangan Lego-Park di Kota Batu dengan Pendekatan Arsitektur Transformasi (Skripsi). Diakses dari http://etheses.uinmalang.ac.id/12377/1/13660053.pdf 
Tanjaya, F. A. \& Wibowo, M. (2014). Perancangan Interior Lego Day Care Centre di Surabaya. 2(2), 222-228.

Gooeir, M. K., \& Wonoseputro, C. (2018). Fasilitas Eduwisata Lego House di Surabaya. VI(1), 113-120.

https://andreasencyclopedia.blogspot.co.id/2014/10/arsitekt ur-modern-tipe-cubism.html (20 September 2019) https://komunita.id/2017/08/29/klub-legoindonesia-komunitas-penggemar-lego-pertamadi-indonesia/ (17 Mei 2020)

https://www.brosispku.com/berita/baca/62/legocreative-carnival-hadirkan-character-ninjagodan-contractor-di-mall-ciputra-pekanbaru (17 Mei 2020)

https://duniaku.idntimes.com/geek/mainan/colonyc oid/klub-lego-indonesia-komunitas (17 Mei 2020) 